\title{
Budget Institutions and Political Insulation: Why States Adopt the Item Veto
}

\author{
Rui J. P. de Figueiredo, Jr.
}

First version: January 1997 This version: June 2002

\begin{abstract}
Forty-three of the fifty states of the United States have granted item veto authority to their governors as part of state constitutions. In this paper, I test explanations of why and when a legislature would cede institutional power. Using data from 1865 to 1994, I show that these measures are most likely proposed by fiscal conservatives who fear the loss of power in the future; in order to protect their interests for those periods when they will be in the minority, they implement institutions such as the item veto which will limit future, liberal legislatures. The results therefore shed light on two important substantive areas. First, by showing how the choice of budgetary institutions is endogenous to the political process, it clarifies that they are not necessarily adopted for economic efficiency. Second, it provides evidence in support of theories that have posited that electorally weak groups will heavily 'insulate' policies in periods in which they momentarily hold power (e.g. Moe 1989, de Figueiredo 2002).
\end{abstract}

JEL Classification Codes: D72, H5, H7

Author keywords: line-item veto, public budget institutions, political economy

* Haas School of Business and Department of Political Science, University of California at Berkeley. The author can be reached at: S-545 Student Services \#1900, University of California, Berkeley, CA 94720-1900 or rui@haas.berkeley.edu. The author gratefully acknowledges Michael Bailey, Severin Borenstein, Brandice Canes-Wrone, John de Figueiredo, John Ferejohn, Brian Gaines, Paul Gertler, Daniel Kessler, Keith Krehbiel, Jeff Macher, Nolan McCarty, Terry Moe, Douglas Rivers, Pablo Spiller, Richard Vanden Bergh, Barry Weingast, two anonymous reviewers, and seminar participants at Stanford University, University of California at Davis and University of California at San Diego, for helpful comments and conversations. The author also gratefully acknowledges Brian Gaines, Richard Sylla, John Legler, John Wallis and Martin Colaco, for assistance with the collection, provision, and cataloging, of the data used in this analysis. Special thanks go to Briana Blower and Conor O'Dwyer for excellent research assistance. Finally, the author would like to recognize the United States Department of Education, under the Jacob Javits Fellowship Program, and the Institute of Governmental Studies at the University of California, Berkeley, for providing funding for this project. All faults are solely the author's. 


\section{Introduction}

Forty-three of the fifty states of the United States have granted item veto authority to their governors as part of state constitutions. Primarily, the legislative bodies in those states have proposed these provisions. In so doing, legislative majorities have relinquished some control over their own fates - their ability to provide legislative pork, obtain programs, and so on - to other institutional actors. This presents a puzzle: why would a majority party in a legislature cede institutional power to its opponents and the executive? One possibility, implied by Cox and McCubbins (1993), is that legislatures allow themselves to be disciplined as a way of overcoming a collective action problem. But in the Cox and McCubbins argument, legislative majorities do not release power to their opponents but to their leaders. A second plausible theory is that, in the same spirit as Cox and McCubbins, legislators recognize they need to constrain their own behavior in order to avoid collective action problems, and therefore, collectively, they choose an institutional structure that effectively accomplishes such control. Again, however, this argument does not explain why particular parties would do this, after they have obtained power. ${ }^{1} \mathrm{~A}$ third possible explanation, also in the same vein, is that if not for political expediency, legislatures adopt mechanisms such as the item veto to improve economic performance and efficiency.

This paper addresses the question of why legislative majority parties will cede institutional power to governors and their opponents in the legislature over perhaps the most important source of legislative rents: the budget. I analyze three types of explanations for proposal of the line-item veto. One possibility accords with conventional wisdom: fiscal conservatives adopt such veto measures as a way of reducing a state's budget. Second and relatedly, such provisions could be adopted as a means for legislatures to address collective action problems, such as the much-discussed fiscal commons problem. Finally, I consider explanations based on a dynamic notion of policy implementation and policy insulation. According to this argument, groups that feel their prospects of retaining power are weak will attempt to "insulate" their policies from future interference (Moe 1989, 1990; de Figueiredo

\footnotetext{
1 For similar arguments about institutional methods of overcoming commitment problems, see, e.g. Weingast and Marshall 1988; North and Weingast 1989.
} 
2002; Vanden Bergh and de Figueiredo forthcoming). I argue that the line-item veto can be considered precisely such an insulation mechanism. Exactly who will have such a use of the item veto, however, depends on the effects of the item veto, over which the existing literature is divided. One view is that the item veto (weakly) reduces state budgets. If we maintain this view, then fiscal conservatives will be most likely to pass it when they feel their hold on the legislature is tenuous. Alternatively, if as others argue, it does not reduce budgets, but simply shifts power from the legislative majority to the governor and legislative minority, it will be used by both fiscal conservatives and liberals when either's future prospects are weak. Rather than choose a singular assumption about the effects of the item veto, I utilize both potential views in my empirical specification and test. ${ }^{2}$

I test these explanations in a multivariate context using panel data from 1866 to 1994 on line-item veto adoption dates, partisan compositions of state legislatures and governorships, and state financial data. The analysis provides evidence that the line-item veto is proposed by conservative legislators, irrespective of who is likely to hold the governorship, but only when these conservatives perceive their future prospects of winning the legislature to be weak. The analysis also shows that a sharp fiscal commons problem does not increase the likelihood of adoption. These results have applications in two areas. First, they provide test case evidence in favor of the theory that adoption of costly and durable institutions that shift power to minorities will occur only when the sitting majority perceives its future electoral fortunes as dim. Second, explaining the adoption of budgetary institution is important in its own right as the analysis also speaks to the literature on the institutions of public finance. While the brunt of this literature focuses on the effects of the line-item veto and other budget institutions, there is very little scholarship on the conditions under which these institutions are adopted. The results here move the level of explanation back one step: making the adoption of the institutions themselves the dependent variable. The paper therefore also contributes to the burgeoning literature on "endogenous budgetary institutions," which argues that budget and

2 It is important to note that my interest here is not in determining the effects of the item veto. These effects are simply maintained assumptions for my current purpose: testing hypotheses of power insulation by weaker parties in legislatures. With either maintained hypothesis, the theory can be tested. For this reason, I do not arbitrate between the two competing possible maintained hypotheses. Instead I assume each is conditionally true, and operationalize the theory using both, which provides the most general test of the insulation theory. 
taxation institutions are not adopted for welfare-maximizing or efficiency reasons, but must be considered in light of their political consequences (see, e.g., Poterba 1994, 1996).

The paper proceeds as follows. In section 2, I posit hypotheses to explain the adoption of the item veto mechanism: that conservatives will adopt it; that they are adopted to overcome fiscal commons problems; and that they are adopted as an insulation mechanism. This last, dynamic hypothesis is operationalized two ways, depending on whether we assume that the item veto simply reduces budgets or that instead, it shifts power between parties and institutional actors. In the case of the former, fiscal conservatives will be more likely to adopt the item veto, but in contrast to the first hypothesis, only when conservatives have been historically weak. In the case of the latter, both conservatives and liberals will adopt the lineitem veto, but only when their prospects of holding the legislature are weak and the governorship strong. In section 3, I describe the sources and issues for the data I use in the empirical analysis. In section 4, I address how to operationalize "fiscal conservatives." In particular, I analyze fiscal spending patterns of different parties in different periods to develop a proxy for control by fiscal conservatives based on partisan majorities. In section 5, I describe the construction of the measures and describe the data. In section 6, I outline my econometric methods and describe the results. The evidence supports only one explanation: that fiscal conservatives will adopt the line-item veto when their electoral prospects are dim, providing support for the theory of institutions as insulating mechanisms. Finally, in section 7 , I offer some concluding remarks.

\section{The Effects of the Line-item Veto and the Implications for Adoption}

Prior to any explanation of why the line-item veto is adopted, it is necessary to consider what the actual or perceived effects of the line-item veto are. Certainly those who adopt the veto would only do so if they felt it would help them achieve their objectives. There is a large body of literature, both theoretical and empirical, on the effects of the line-item veto. Unfortunately, there is disagreement in this literature about the impact of the line-item veto. One view is that the item veto is budget reducing. It is this rhetoric that the public proponents of the line-item veto use in arguing its virtues. The veto authority is asymmetric, governors can only reduce budgets with it, so it must have a weakly budget-reducing effect, these 
scholars argue. Holtz-Eakin (1988) finds, for example, that under certain political conditions, the item-veto does reduce aggregate spending, although his results are not conclusive on this point. As Alm and Evers (1991) conclude, "The results...suggest that the item veto has a small and negative impact in total." ${ }^{3}$ According to this view, budgetary politics should be seen on a single dimension of more or less spending, and the effect of the item veto is to simultaneously shift power to the governor and reduce budgets.

Despite this view, other studies have found both theoretical and empirical evidence that the line-item veto does not have the large effect on aggregate spending originally assumed. For example, Dearden and Husted (1993) propose a spatial model that compares the absolute and item vetoes. They conclude that the line-item veto shifts power from the legislatively strong to the legislatively weak and particularly to the governor, and therefore, can either reduce $o r$ increase budgets, depending on who holds public office. Thus, they argue, while the item veto does not drastically reduce aggregate expenditures, it reallocates spending among programs, issues and policies. In other words, they view budgetary politics as multidimensional, with the item veto simply shifting the policy location on an iso-spending plane.

These assumptions are utilized to examine the adoption of line-item veto measures as a dependent variable. ${ }^{4}$ Rather than attempt to adjudicate between the two conflicting results on the budgetary effects of the item veto, I operationalize hypotheses based on both. The hypotheses broadly fall into three explanatory categories: static ideological (or partisan) preferences which holds that political parties adopt the item veto as a way to induce policies that they prefer; "efficiency" concerns which holds that states are more likely to adopt the item veto when the fiscal commons problem is most severe; and dynamic ideological or insulation concerns which holds that parties with a tenuous hold on power use the item veto as

3 See also Abrams and Dougan 1986; Rowley, Shughart, and Tollison 1987; Crain and Miller 1990; Carter and Schap 1990. It is worth noting that this stream of the literature does not maintain that budgets are always reduced, but only under certain conditions. For the purposes here, this is sufficient to act as an incentive (perhaps weak) for adoption.

$4 \quad$ It is important to note that in most cases, the item veto is adopted as an amendment to the constitution. In general, the paths to amendment of state constitutions vary. In this case, for every amendment or full constitution adopted by the states, there has been a two-stage process of proposal by the legislature and approval by the voters. It is certainly the case that the legislature will condition their proposal on anticipation of approval, this means that not every opportunity will be taken. Thus, the conditions posited here should be interpreted as necessary for approval, enhancing the probability of adoption. In practice, the constraint placed on legislatures by citizen approval is largely minimized with the line item veto because, in general, most voters prefer to provide for strong budgetary responsibility. 
a mechanism to lock in policy benefits when they anticipate they will be (frequently) out of power.

Using these broad classes of explanatory factors, I posit a number of hypotheses. The first of these, the conservative hypothesis, holds that it is largely fiscal conservatives who want to enact line-item vetoes. According to this argument, an interest in spending reduction leads fiscal conservatives to adoption of line item veto measures.

Hypothesis 1 (H1): Legislative control by fiscal conservatives will, on average, increase the probability that the line-item veto will be adopted.

A second hypothesis, which I term the efficiency hypothesis, is that the line-item veto is adopted by states which face a severe fiscal commons problem; in other words, the institution is adopted to improve the efficiency of government policy by limiting the ability of the legislature to overspend on pork. To operationalize this explanation, I examine both direct and indirect identifiers of a fiscal commons problem. The first way of identifying the effect of fiscal commons problem is that the line-item veto is more likely to be adopted when there is significant debt or budget deficit in a particular state. As fiscal policies become more extreme, a legislature is more likely to adopt a budget-reducing measure such as the line-item veto.

\section{Hypothesis 2a (H2a): The line-item veto is more likely to be passed when a state's} fiscal position becomes increasingly worse.

A second measure of the fiscal commons externality is the size of the legislature. As Weingast, Shepsle, and Johnson (1981) point out, as a legislature becomes larger, the legislature faces a greater collective action problem in curbing profligate spending. Further, this claim has found empirical verification in the work of Gilligan and Matsusaka (1995, 2001), Bradbury and Crain (2001), and Pettersson-Lidbom (2001), all who find that differing institutional and geographical contexts, the number of legislative seats is a robust predictor of government spending. This suggest that larger legislatures are more likely to adopt the lineitem veto if motivated by "efficiency." 
Hypothesis $2 b$ (H2b): The line-item veto is more likely to be passed in states where the number of legislative seats is larger.

The insulation hypotheses are based on a formal theory of policy insulation developed elsewhere (de Figueiredo 2002; see also Vanden Bergh and de Figueiredo forthcoming; Moe $1989,1990)$. According to this theory, when a historically weak party or group gains power, it will be more likely than historically strong parties to adopt mechanisms that trade benefits when they are in power for benefits when they are not in power. The rationale behind this argument is that if insulation is costly, those who are most likely to have their programs sabotaged are the most willing to pay those costs. ${ }^{5}{ }^{6}$ How this type of dynamic thinking will be implemented, however, depends on the effects that the item veto is believed to have.

By definition, if budgetary politics can be reduced to one dimension, conservatives want less spending than liberals. If the item veto is perceived to be an aggregate budgetreducing mechanism in a one-dimensional policy fight, it will be more attractive to fiscal conservatives, as noted in $H 1$. The question raised based on this maintained hypothesis, however, is why would conservatives be willing to cede power to the governor in order to reduce budgets if they could retain such power themselves? The answer lies in insulation. If conservative legislators feel they can retain power, they have no incentive to allow budgets to be reduced further, since they are already obtaining spending at a level near their ideal points. The item veto will only serve to move policy farther from their optimum. If a sitting conservative legislature feels it will usually be out of power in the future, however, it has a

5 To be precise, a mechanism will meet this criteria if it has three characterisics: first, it must shift rents from majorities to minorities; second, it must be durable; third, it must carry "policy costs." For a more detailed discussion see de Figueiredo 2002; Moe 1989, 1990.

6 An important clarifying point here is that the item veto has exhibited, both empirically and theoretically, remarkable durability. Indeed, for an institution such as the line item veto to be considered an "insulation mechanism," it is necessary to explain why the instrument is not reversed when the adopters fall out of power. There are a number of reasons to believe the item veto exhibits such durability. First, as I note later, empirically, no state that has ever adopted an item veto has ever repealed it. This provides initial evidence for such durability. Further, theoretically, there are a number of reasons why the conditions for reversal ex post are not the same as those for adoption ex ante. As noted earlier, since these provisions are uniformly adopted upon proposal by legislatures and approval by voters, adoption and revocation are conditional on support from the voters. Here, a review of the histories in a number of states indicates that voter support is usually in favor of budget restraint mechanisms, therefore making it easier to adopt the measures than to revoke them. Further, governors have a strong incentive to enhance their own institutional power. Thus, governors' interests are also asymmetric (Moe 1989). While governors will use their institutional to support adoption of the item veto, once it 
greater incentive to pay the price of ceding budgetary authority for times when they hold the legislature: when they lose control, spending will be lower with the line-item veto than without it, and therefore, closer to conservatives' preferences. No matter which party holds the governorship, conservative legislatures will do better by shifting power away from the legislative majority. Since the item veto, I assume here, simply reduces budgets, conservatives will gain benefits of such a reduction in many periods, losing only on the rare occasions they are in power. ${ }^{7}$ This analysis suggests the conservative insulation hypothesis:

\section{Hypothesis 3 a (H3a): The line-item veto is more likely to be passed by fiscal} conservatives when they have been historically weak. ${ }^{8}$

Notably, H3a can be contrasted with H1. In the latter case, conservatives uniformly want budget reductions and therefore the item veto. In contrast, under $\mathrm{H} 3 \mathrm{a}$, which takes account of a dynamic calculus, proposal of the line-item veto depends on the interaction of conservative control and their belief that they will be out of power most of the time.

In the previous case the party of the governor did not matter: conservatives gain from the line-item veto, irrespective of whether a fiscal conservative or fiscal liberal holds the governorship. This result was based on an assumption about the uni-dimensionality of budgetary politics. An alternative assumption one could make, however, is that while the item veto does not reduce spending, it shifts allocations from the legislative majority to the governor and legislative minority in a multi-dimensional policy space. In this case, the governor's party does matter. Since governors will be like legislators of the same party, conservatives and liberals alike will only cede such power when they feel the governor will be of their own party. In the context of the line-item veto, this suggests an explanation for when a legislature will propose the line-item veto: a party that considers itself to be traditionally

has been passed, they will fight against repeal. Combined with the incentives of voters, the asymmetric nature of governors' interests makes revocation of the item veto unlikely.

7 It is useful to clarify why the conservatives will suffer losses when in power under the item veto. The reason is that they cede partial control over the final budget to the governor. Thus, both the size and composition of spending will vary from the legislature's preference, making the majority in the legislature worse off.

8 Note that this hypothesis is stated in terms of historical electoral positions. I use a party's historical electoral results as a way of estimating the party's subjective estimate of its long term electoral prospects. That parties rely on their historical performance to estimate their subjective probabilities is a maintained hypothesis. Alternative maintained assumptions, such as a prospective calculus, are also tested, as I will discuss later. 
electorally weak will pass a line-item veto if it does gain power and that their party will be represented in the governorship. Thus, as an alternative test of the insulation theory, I have the non-partisan insulation hypothesis:

Hypothesis $3 b(H 3 b)$ : The line-item veto is more likely to be passed if:

(i) there is undivided control by a party of both houses of the legislature in which that party has a large enough majority to pass amendments

(ii) that party is historically weak

(iii) that party historically holds the governorship. ${ }^{9}$

I term this the non-partisan hypothesis because in contrast to $\mathrm{H} 3 \mathrm{a}$, both conservatives and liberals will act in similar ways under the conditions posited. In one sense, however, nonpartisan is a misnomer, since if $\mathrm{H} 3 \mathrm{~b}$ is true, the legislative actors are keenly concerned about the likely partisanship of future public officials.

\section{Data Sources and Issues}

Data Sources. To test the effects of partisanship on the adoption of the line-item veto by state governments, I use three types of data. The first is the adoption dates for line-item veto provisions in the states. As of 1996, forty-three of the fifty states had adopted some lineitem veto provision. These dates were collected from the annotated state constitution for each state and the U.S. House Committee on Rules' Item Veto: State Experience and Its Application to the Federal Situation. The Book of the States was used to obtain the proposal and passage requirements for amending each state's constitution. ${ }^{10}$ The information is contained in Table 1.

\footnotetext{
$9 \quad$ Note that $\mathrm{H} 3 \mathrm{~b}$ is a very sharp prediction for a number of reasons. First, it bases the prediction not only on current considerations but also past and future ones. Second, these conditions obtain relatively rarely. This is true in part, by definition, since conditions (i) and (ii) require that the current supermajority party must usually be in the minority. Further, conditions (ii) and (iii) require that divided government must have recently occurred. Empirically, there was divided control of the legislature and the governorship for about thirty percent of the state legislative sessions from 1866 to 1994. As an interesting aside, the requirement for (super)majority control and undivided legislatures is not very stringent. As a rough estimate, one party had supermajorities large enough in both legislative chambers to propose and/or pass amendments in as many as eighty-six percent of these cases.

10 Note that Table 1 lists the current supermajority requirements necessary for proposal. Data for the requirements in each state over time would be superior, but are not reliably available.
} 
Although there is variation in the type of provision—some states allow governors to amend lines rather than just strike them, for example - for the purposes of this analysis, I assume that the critical aspect of the veto is adoption. ${ }^{11}$ Two features of these adoption dates are important to note. First, the line-item veto originally appeared in an American institutional context when it was part of the constitution adopted by the Confederacy prior to the Civil War. The first appearance of such a provision at the state level was in 1865, when both Texas and Georgia included it as part of the post-War rewrites of their state constitutions. Second, no state that has adopted the provision has later rescinded it.

The second set of data is the partisan composition of each state legislature and governorship. These data were obtained from 1830 to 1995 from a number of sources. Most importantly, the data were gathered for 1830 to 1985 by Walter Dean Burnham and is contained in a data set available from the Inter-University Consortium for Political and Social Research (ICPSR), titled Partisan Divisions Among the States, 1830-1985. This data has been updated - including corrections to errors, elimination of missing data, and inclusion of the years 1986 to 1995- using a number of sources including The Statistical Abstract of the United States, The Tribune Almanac and The Book of the States, from various years.

The third set of data used in the analysis is state government financial data. Again the complete time series has been collected from a number of sources. For the years 1865 to 1915, data was obtained from another ICPSR data set collected by Sylla, Wallis and Legler, titled Sources and Uses of Funds in State and Local Governments, 1790-1915: United States. Since 1915, the United States Bureau of the Census detailing state government finances has kept public records. The data in this paper were obtained from three sources provided by the Census Bureau, depending on the dates. From 1915 to 1941, the data were obtained from a series called Financial Statistics of the States. From 1942 through 1964, the data were obtained from The Compendium of State Government Finances series. And for 1965 to 1981 , they were obtained from the State Government Finances Series. From 1981 to 1995, the data

11 Item veto authority comes in very different forms. The standard conception is that a governor can veto particular items in appropriations legislation. Fisher and Devins (1986: 166), however, point out that a number of states have adopted one of three modifications of the traditional item veto. First, some states have item-reduction vetoes as well, in which a governor does not have to eliminate a proposed expenditure entirely, but can also reduce it. A second modification on the traditional line-item veto is the amendatory veto. In this case, a governor can condition the veto on approval of amendments to be adopted by the state legislature. Finally, some governors, have item veto authority on non-appropriations items within appropriations bills. 
were updated from The Statistical Abstract of the United States. Finally, statistics on state populations and national inflation rates were obtained from Historical Statistics of the United States: Colonial Times to 1970, Volumes 1 and 2. ${ }^{12}$

Table 1. Adoption Dates of Line-item Veto

\begin{tabular}{|c|c|c|c|c|c|}
\hline State & Year & $\begin{array}{l}\% \text { Majority } \\
\text { Required }\end{array}$ & State & Year & $\begin{array}{l}\text { \% Majority } \\
\text { Required }\end{array}$ \\
\hline Alabama & 1875 & 60 & Montana $^{\mathrm{a}}$ & 1889 & 67 \\
\hline Alaska $^{a}$ & 1960 & 67 & Nebraska & 1875 & 60 \\
\hline Arizona $^{\mathrm{a}}$ & 1911 & 50 & Nevada & No provision & 50 \\
\hline Arkansas & 1874 & 50 & New Hampshire & No provision & 60 \\
\hline California & 1879 & 67 & New Jersey & 1875 & 50 \\
\hline Colorado $^{a}$ & 1876 & 67 & New Mexico ${ }^{a}$ & 1912 & 50 \\
\hline Connecticut & 1924 & 50 & New York & 1874 & 50 \\
\hline Delaware & 1897 & 67 & North Carolina & No provision & 60 \\
\hline Florida & 1875 & 60 & North Dakota ${ }^{a}$ & 1889 & 50 \\
\hline Georgia & 1865 & 67 & Ohio & 1903 & 60 \\
\hline Hawaii & 1960 & 67 & Oklahoma $^{\mathrm{a}}$ & 1907 & 50 \\
\hline Idaho $^{a}$ & 1889 & 67 & Oregon & 1916 & 50 \\
\hline Illinois & 1884 & 60 & Pennsylvania & 1873 & 50 \\
\hline Indiana & No provision & 50 & Rhode Island & No provision & 50 \\
\hline Iowa & 1968 & 50 & South Carolina & 1895 & 67 \\
\hline Kansas & 1903 & 67 & South Dakota ${ }^{a}$ & 1889 & 50 \\
\hline Kentucky & 1891 & 60 & Tennessee & 1953 & 67 \\
\hline Louisiana & 1879 & 67 & Texas & 1866 & 67 \\
\hline Maine & No provision & 67 & $\mathrm{Utah}^{\mathrm{a}}$ & 1895 & 67 \\
\hline Maryland & 1891 & 60 & Vermont & No provision & $67 / 50^{\mathrm{b}}$ \\
\hline Massachusetts & 1918 & 50 & Virginia & 1902 & 50 \\
\hline Michigan & 1908 & 67 & Washington $^{\mathrm{a}}$ & 1889 & 67 \\
\hline Minnesota & 1876 & 50 & West Virginia & 1872 & 67 \\
\hline Mississippi & 1890 & 67 & Wisconsin & 1930 & 50 \\
\hline Missouri & 1875 & 50 & Wyoming $^{\mathrm{a}}$ & 1889 & 67 \\
\hline
\end{tabular}

Missing Data and Measurement Problems. There are a number of issues concerning the data that must be dealt with. First, there is a significant proportion of missing data in the

12 Note that since state population data was only available for each decade, a linear interpolation was 
financial series. Some years are completely missing (1920, 1932 through 1936, and 1972). In addition, particularly in the ICPSR data for years prior to 1915, there are frequently missing observations. To deal with this problem, in reporting the results I test the models on the full data without the financial measures, and on the subset for which the financial measures are available. Second, there are accounting issues that potentially make incomparable the data that is obtained from different sources. In the analysis below, where financial measures have been used to measure changes in financial positions, the first year in which data was obtained from a new source (for example, in 1915, I switch from the ICPSR data on state expenditures to the Census Bureau figures), I omit that year to ensure comparability. For example, the change in spending from 1914 to 1915 is suspect, so these observations are omitted from analysis involving changes in expenditures.

\section{Partisan Fiscal Patterns}

To operationalize the hypothesis that conservatives are more likely to pass a line-item veto, it is necessary to designate when conservative interests control the legislature. Our approach here is to use party control as a proxy for current interest group supremacy. This begs the question, however, of which party we should use as a proxy for conservative interests.

Notably, while conventional wisdom states that the Republicans supported lowerspending in the post-Progressive Era, the literature on this subject has received at best, mixed results. Further, with the notable exception of Gilligan and Matsusaka (2001), there is very little evidence about state partisan spending patterns prior to World War II. Alt and Lowry (1994), for example, examine state spending patterns in the period from 1967 to 1988 . They find that Republicans, on average, want to spend 6.7 percentage points of personal income less than Democrats at the state level. While suggestive, their evidence focuses on the sensitivity to income changes at the margin, rather than absolute levels of expenditures. On the other hand, in two separate papers, Gilligan and Matsusaka $(1995,2001)$ examine state spending patterns in the twentieth century, before and after WWII, and find that while variables that control for constituent preferences and institutional features, such as the size of

applied to calculate the yearly totals for each state. 
the legislature, are significant, very little evidence can be found for first-order effects of parties.

This inconsistency in the evidence makes it difficult to resolve how to operationalize "lower spending" interests. If constituent characteristics, and not party, determine expenditure levels, this raises concerns about the use of party as a measure of fiscal conservatism. First, if the literature is accurate, then the use of constituent characteristics rather than party might represent better measures of the fiscal interests of the majority. Second, if politicians are "faithful agents" of voters, and voters have a temporary interest in increasing spending, it would not necessarily imply that they would want to "insulate" those interests. Ideally, therefore, one would tease out the patterns of state spending using a model which controls for both stable state-specific effects and temporal shocks, and also includes time-varying measures of both state institutional characteristics and constituent preferences (following Gilligan and Matsusaka 1995, 2001). Unfortunately, the absence of reliable measures to control for constituent preferences spanning the post-Civil War period to the present is unavailable.

That said, the task for our present purposes is not unredeemable. There are a number of reasons for this. First, and most importantly, my objective is different than that of the existing literature on the size of state government. The existing literature is primarily interested in the question of what independent effects explain the size of government; in other words, do parties have an independent effect on the size of government, or does the election of a party simply signal that the constituents want larger or smaller government at that time? For the present purposes, however, I am only using the party as a proxy for the political environment at the time, whether it be directly from the party or of constituent interests via a party. In other words, I am trying to estimate the effect of what might be termed idiosyncratic superiority of a particular set of interests, as represented by the parties. Even if the parties themselves do not have a primary effect on spending, as Gilligan and Matsusaka find, as long as the election of a party reflects the emergence of a particular set of fiscal interests, then the theoretical concepts, particularly with respect to dynamic considerations, will be reasonably measured. On the other hand, the time-invariant effects of non-idiosyncratic, or stable constituent preferences will be picked up by the state fixed effects. Second, even if one assumes that the parties are faithful agents of the voters, using party majorities as such a proxy can still be appropriate. In 
this case, at worst, it will only make it harder to identify effects in the later analysis. Further, if we take a more fluid view of the electorate, then the median voter in the electorate might also be unstable. To that extent, current voter majorities (medians) might still be willing to insulate their policies in anticipation of a shifting electorate.

Thus, in order to obtain a measure of which party, possibly as a result of constituent preferences, was lower-spending, I employ the larger data set on state spending patterns. In particular, I use a two-way error component fixed effects model. The measure used for the dependent variable is the natural logarithm of per capita state government spending, $\log \left(P_{C S P E N D}{ }_{i t}\right)$. The independent variables are the sum of the Republican plurality in the lower and upper houses, $R L E G P L U_{i t}$, and a dummy variable for a Republican governor, $R G O V_{i t}$. Note that states are indexed by $i=(1, \ldots, N)$ and years are indexed by $t=(1, \ldots, T)$. Thus, the model is:

$$
\log (P C S P E N D)_{i t}=\alpha+\beta_{1} R L E G P L U_{i t}+\beta_{2} R G O V_{i t}+\mu_{i}+\lambda_{t}+v_{i t} \quad \text { with } \quad v_{i t} \sim N\left(0, \sigma^{2}\right)
$$

where the $\mu_{i}$ 's represent state-specific effects, the $\lambda_{t}$ 's represent year-specific effects and the $v_{i t}$ 's are normally distributed disturbances with mean zero and variance $\sigma^{2}$ (Baltagi 1995: Chs. 2 and 3; Greene 1993: Ch. 16).

A final issue is what are the appropriate periods by which to estimate these partisan effects. Although in the modern era, the spending preferences of the two parties is fairly well understood, in the period after the emergence of the Republican Party until the Progressive Era, this might not necessarily be the case. Indeed, at the national level, in the pre-Progressive period, the southern-slanted Democrats were against the tariff, which was the primary source of revenue prior to the implementation of the national income tax. Thus, the national party was, in general, against substantial government spending, which would require higher tariffs for off-setting revenue. After the institution of the national income tax by the Democrats in 1913, the parties positions' shifted at the national level, until ultimately, with the implementation of the New Deal in the post-Depression era, the Democrats and Republicans 
took on their more modern guises (Johnson and Porter 1973). ${ }^{13}$ Our task, therefore, is to determine if this general pattern, which held at the national level, was also true at the state level.

I therefore estimate the model on the post-Civil War observations prior to the posited cutpoint year of 1913, excluding the observations from Nebraska and Minnesota, since these states are omitted in the later analysis. The results of the analysis are reported in Table 2 . The first column gives the results for the period of interest, from 1866 to 1912 . Recall that I am testing for a difference between Republican and Democratic legislative strength on changes in the level of spending by state governments. Thus, our hypothesis is that $\beta_{1} \neq 0$.

Table 2. Partisan Spending: OLS Estimates

\begin{tabular}{|c|c|c|c|c|}
\hline $\begin{array}{l}\text { Dependent Variable: } \\
\log \left(P C S P E N D_{i t}\right): \log (P e r \\
\text { Capita Spending })\end{array}$ & $\frac{\text { Excludins }}{1866-1912}$ & $\frac{\text { Seats }}{1913-1970}$ & $\frac{\text { Includin }}{1866-1912}$ & $\frac{\text { Seats }}{1913-1970}$ \\
\hline$R L E G P L U$ & $\begin{array}{c}0.127 \\
(0.036)\end{array}$ & $\begin{array}{l}-0.063 \\
(-3.01)\end{array}$ & $\begin{array}{c}0.140 \\
(0.036)\end{array}$ & $\begin{array}{l}-0.064 \\
(-3.01)\end{array}$ \\
\hline$R G O V$ & $\begin{array}{l}0.033 \\
(0.29)\end{array}$ & $\begin{array}{l}-0.006 \\
(0.016)\end{array}$ & $\begin{array}{c}0.033 \\
(0.029)\end{array}$ & $\begin{array}{l}-0.006 \\
(0.016)\end{array}$ \\
\hline TOTSEAT & & & $\begin{array}{c}0.000 \\
(0.000)\end{array}$ & $\begin{array}{c}0.000 \\
(0.001)\end{array}$ \\
\hline $\begin{array}{l}R \text {-squared } \\
n\end{array}$ & $\begin{array}{l}0.79 \\
1245\end{array}$ & $\begin{array}{c}0.96 \\
2244\end{array}$ & $\begin{array}{l}0.79 \\
1245\end{array}$ & $\begin{array}{c}0.97 \\
2244\end{array}$ \\
\hline
\end{tabular}

As Table 2 indicates, there are significant differences between Republican and Democratic state legislatures in the Pre-Progressive Era. The coefficient of $R L E G P L U_{i t}$ is highly significant at any conventional level. Further, because it is positive, I can make a more positive statement that is of use in the later analysis: Republicans were higher spenders at the

13 The income tax was first adopted in 1861, but was quickly repudiated after the crisis of public finance born by the Civil war had passed. Later, in 1894, Congress passed another income tax, but the Supreme Court struck it down the following year. (Arnold 1990: 195) 
state level in the period before 1913. For purposes of validation, I ran a similar regression on the period from 1913 to 1970 . Here, I obtain the result that conforms to intuition that Republicans tend to be lower spenders in the post-Progressive era. This gives credence to the structure of the regression specified above. Further, even when a control is introduced to include the total number of legislative seats, the results remain almost identical. ${ }^{14}$

While these results do not allow identification of partisan effects that are independent of constituency effects, they do allow me to operationalize "conservative" interests: before 1913, Democrats were the fiscal conservatives, while after 1913, Republicans were. I will use this basic result, then, in the analysis of adoption probabilities of the item veto. In addition, as a further robustness check, I also broke the sample in the adoption regressions into subperiods to verify that the results were not subject to problems in the pre-Progressive Era based on this specification.

\section{Measures and Descriptive Statistics}

Measures. In order to test potential explanations of line-item veto adoption, I construct a number of measures. First, I use the dates in Table 1 to construct a dummy variable for whether the line-item veto was passed in a particular year. ${ }^{15}$ I call this variable $A D O P T_{i t}$,

14 In it is interesting to note that the coefficient of TOTSEAT $T_{i t}$ is not significant, a result which runs counter to the finding in Gilligan and Matsusaka (2001). As noted earlier, my intention here is not to test direct effects, but instead to see whether we can use party majorities as an indicator of changes in state majorities on changes in spending preferences. This has two implications. First, the result might be in part because the full specification employed by Gilligan and Matsusaka is not possible here; adding appropriate controls might change the coefficient of total seats. Further, because there is not a significant change in the number of seats over time, most of the constituent effects are likely soaked up in the fixed state effects. Second, and perhaps more importantly, because the model I employ includes fixed state effects, I am unable to break out upper and lower house number of seats separately, without introducing linear dependence. Therefore, I obtain a noisier result and am unable to separate the effects of the lower and upper houses, as Gilligan and Matsusaka do. When they do so, they find that the upper house has significant impacts on spending, but not the lower house.

15 In every state, while legislatures have the prerogative to propose constitutional amendments, they must be approved by a referendum. Legislative gatekeeping power means that the conditions that I posit must exist for proposal. A potential problem, therefore, is that this process means that $y_{1}$ is actually a measure of legislative proposals conditional on approval. In other words, I miss two sets of potential proposals: those that are not made because they will not likely pass, and those that are made but do not pass. Although this does introduce a potential bias, I have investigated the histories in a number of states and have not yet found a case in which proposals have been made that were not approved.

In addition, to appropriately match the variables requires that I take account of three state governmental processes: elections, constitutional amendment procedures and budgetary processes. In general, I match all of the variables by legislatures that took the action. Details on this process are available from the author. 
which is one if the line item veto was passed in a particular year, and zero otherwise. Note that $i$ indexes a particular state and $t$ indexes a particular year, and the unit of analysis is a legislature. ${ }^{16}$

The first set of independent variables captures current control over political institutions. The variable $C O N_{i t}$ is a dummy variable for conservative control, which is one if the conservative party, as determined based on section 4, have a supermajority in excess of the state requirement for proposal of an item veto amendment, and zero otherwise. An analogous variable $L I B_{i t}$ measures liberal party control.

An additional set of measures captures the historical strength and weakness of the parties. To measure the historical weakness of the conservatives, I take one minus the percentage of times the conservative party had a majority in both houses in the previous three sessions of the legislatures, which I term HISTCON ${ }_{i t}$. An analogous measure HISTLIB ${ }_{i t}$ is calculated for historical liberal weakness in the legislature. ${ }^{17}$ Similar measures are defined for historical position in the governorship. HISTCONGOV $V_{i t}$ measures the percentage of times in the previous three legislative sessions that the governor is conservative, and HISTLIBGOV $V_{i t}$ is measured analogously for liberal governors.

Two points are worth noting about these partisanship measures. First, these historical measures implicitly assume that elected officials are retrospective in estimating their future chances of winning elections. This would mean that if there is a regime change after a long period of control by one party, both parties would assume that this was an anomaly. An alternative is that elected officials are prospective, that their subjective assessment of their electoral prospects is based on a rational expectation of the outcome. One example of such a process would be if after a change in the partisan composition of the legislature, officials assumed that the change represented a realignment. While I feel that it is more reasonable to assume the retrospective case, I also test the model with prospective measures. Second, the choice of basing the partisan strength measures on three periods is arbitrary. Notably, I chose this based on what I viewed was a reasonable assumption along with a requirement to include

16 In practice, this means considering only the even numbered years for most of the legislatures.

17 The reason to use simple majority rather than supermajority as previously is because after the item veto has been adopted, it operates to constrain the majority from achieving the same outcomes it might have in the absence of the veto. In other words, it operates to constrain normal legislative policymaking which occurs under majority rule. 
as many observations as possible. As noted earlier, as the period over which I calculate historical party strength increases, I am forced to ignore more and more observations at the beginning of the sample. Particularly because many states adopted line-item veto provisions soon after the Civil War, choosing longer lags would mean a significant loss of data. When the models are tested on the sub-samples with longer lags, the results are substantively stable.

I also construct measures to operationalize the idea that a fiscal commons problem might lead to the adoption of the line-item veto. A natural candidate to use for this would be a measure of state debt. Unfortunately, that data are very limited in its availability in the nineteenth century. Another alternative would be to use the size of a state's budget deficit. This measure, however, is inadequate, since many states have balanced budget amendments, and even those that do not, use offsetting revenue programs to counter budget deficits. Thus, based on both availability and validity, I use PCSPENDCH $H_{i t}$ which is a measure of the percentage change in per capita real government expenditures from the previous legislature to the current one. ${ }^{18}$ In addition, as an alternative measure, I use $L H S E A T_{i t}$ and $U H S E A T_{i t}$ which is the number of seats in the lower and upper houses, respectively.

Finally, as a cursory examination of Table 1 might indicate, one concern about the pattern of adoption of the item veto might be that the reconstructed South might be sui generis. To control for this possibility, the variables $E A S T_{i t}, S O U T H_{i t}, M I D W E S T_{i t}$, and $W E S T_{i t}$ are dummy variables indicating if the state is in a particular region (coded as a one) or not. $^{19}$

Descriptive Statistics. Before turning to more sophisticated econometric analysis, it is useful to examine the characteristics of the data. Table 3 provides descriptive statistics for all of the variables used. Perhaps more instructive, however, in Table 4, I present the distributions of the partisan compositions of the legislature, as a function of the historical composition of the legislature. In each cell are two quantities: the quantity in the upper left hand corner is the proportion of observations in the cell in which the item veto was adopted; the quantity in the lower right hand corner is the proportion of total observations in the sample

\footnotetext{
18 An even better measure of spending would be per capita expenditures as a percent of gross domestic product, however, these data are not available on an annual basis in the early period of the data set.

19 These are coded following the ICPSR's regional classifications.
} 
that were in the cell. Only the observations on which the later econometric analysis was conducted were included.

Table 3. Descriptive Statistics

\begin{tabular}{lcc}
\hline Variable & Mean & $\begin{array}{c}\text { Standard } \\
\text { Deviation }\end{array}$ \\
\hline \hline ADOPT & 0.031 & 0.174 \\
CON & 0.394 & 0.049 \\
LIB & 0.450 & 0.498 \\
CONGOV & 0.440 & 0.497 \\
HISTCON & 0.599 & 0.449 \\
HISTLIB & 0.529 & 0.443 \\
HISTCONGOV & 0.432 & 0.422 \\
PCSPEND & 493.898 & 689.936 \\
PCSPENDCH & 0.0709 & 0.341 \\
TOTSEAT & 177.994 & 90.361 \\
$n$ & 804 & \\
\hline
\end{tabular}

Note: regional dummy variables excluded

$n$ for PCSPEND and PCSPENDCH $=482$

HISTCON and HISTLIB are scored in terms of increasing weakness (so they sum to more than one)

In this simple form, it is already possible to see patterns in the data. In particular, the probability of adoption under conservative control is, on average, higher than when there is not conservative control. However, the most striking result is that when conservatives are in control but are historically weak, the probability that a line item veto will be adopted rises dramatically. Although this is a rare state, it is the one in which the adoption of the item veto is most likely. This points to preliminary evidence that only $\mathrm{H} 3 \mathrm{a}$, the conservative insulation hypothesis, seems to provide a substantial explanation of item veto adoption. However, as we noted earlier, it is important to examine this hypothesis in a more rigorous fashion. We now turn to that task. 
Table 4. Distribution of Item Veto Adoption and

Partisan Composition of Legislatures

\section{Legislature}

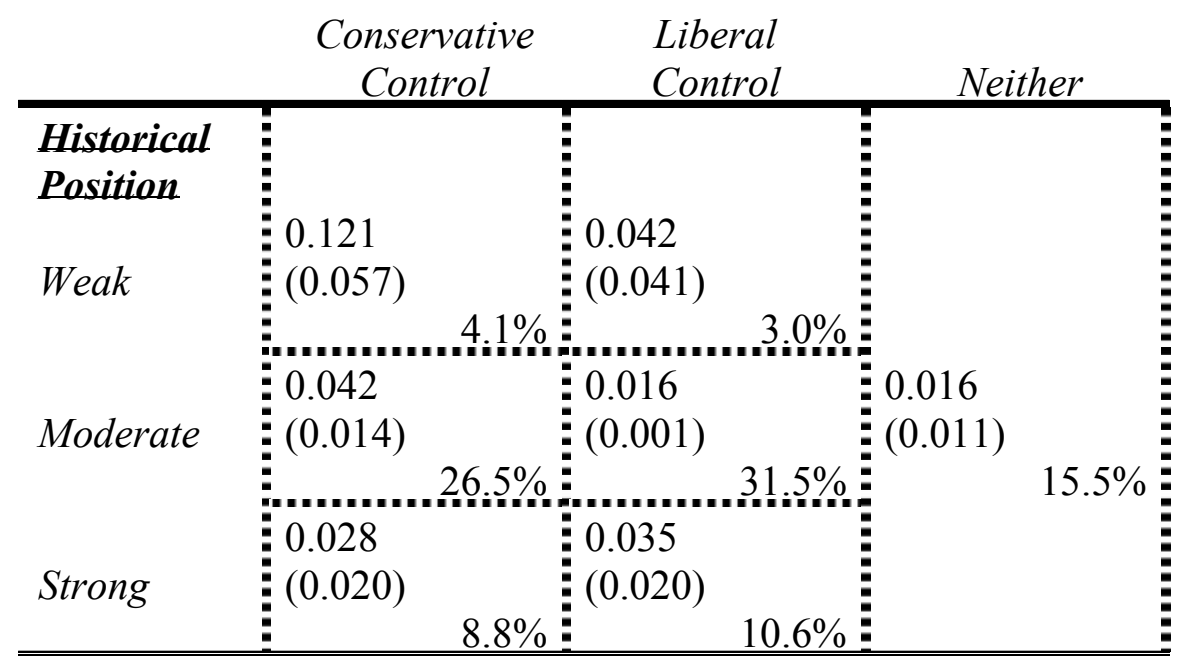

Note: Cells are probability item veto is adopted conditional on being in the cell and proportion of total observations in a particular state; standard errors parentheses

Control means supermajority control

Historical position is based on average of previous three legislatures. They are calculated using 0.33 and 0.67 as cutpoints.

For "neither" no historical position is aggregate over all possible states.

$\mathrm{N}=804$; only includes observations for a legislature up to year of adoptior veto.

\section{Econometric Methods and Results}

Econometric Model. The method of testing the hypotheses concerning the line-item veto is a one-way transition, discrete hazard analysis. I make a number of assumptions about the process of adoption. First, I assume that the factors that drive the decision to adopt are time-independent. In other words, none of the factors are functions of $t$, so $t$ does not appear in the model specification either directly or in any of the covariates. I later relax this assumption in a number of ways. Second, I assume the transition is one-way. In other words, once a provision is adopted it will remain. While this is clearly not institutionally necessary, states can reverse the adoption of the line-item veto, a few facts make this a reasonable simplification. First, as indicated in Table 1, it is extremely difficult to reverse the adoption of a constitutional amendment in most cases. Second, no state has ever reversed a line-item veto 
amendment (Palffy 1994). This means that I eliminate all observations that occur after the line-item veto has been adopted. Finally, I assume that the hazard function can be represented by a standard normal cumulative distribution function.

These three assumptions mean I can represent the event history model as a standard probit in which I condition on the event not yet having occurred. Formally, for a vector of covariates $\mathbf{x}$,

$$
P\left(y_{1 i t}=1 \mid \mathbf{x}_{i t}, y_{1 i s}=0 \text { for } \quad s<t\right)=\Phi\left(\beta^{\prime} \mathbf{x}_{i t}\right)
$$

which can be estimated by the usual maximum likelihood methods for a probit model. ${ }^{20}$

A few points are worth noting about the implementation of this model. First, the panel nature of the data means that there exists the possibility that there is both heteroscedasticity and autocorrelation. Although these problems will not affect the estimates of the coefficients, they will lead, if present, to inconsistent estimates of the standard errors. Therefore, to eliminate this potential problem, I recalculate the standard errors of the estimates using an adaptation of the method suggested by Newey and West (1987). ${ }^{21}$ Second, the full specification includes a number of variables that do not reflect either the hypotheses of interest or controls. Since we are interested in testing hypotheses about interactions, however, this is the appropriate approach. Excluding the main effects would inappropriately bias the results in favor of finding significant coefficients on the interaction terms. Third, because of the lagged variables, it is not possible to estimate this model for states which implemented the line-item veto within six years of admission of the state to the Union. Fourth, the seven states which never passed a line-item veto were included in the pooled sample, although they never have $A D O P T_{i t}=1$. Finally, because of their nonpartisan state politics, I exclude Nebraska and Minnesota.

Before turning to the results, it is useful to consider what would constitute evidence in favor of each of the hypotheses. For evidence of H1, I would expect that the coefficient of $C O N_{i t}$ to be positive. This would mean that if there is a sitting conservative supermajority, the

20 Note that the probit function I estimate can be put into a traditional hazard model framework by transforming the above model into the corresponding probability density function, survivor function and hazard function. See Yamaguchi 1991; Blossfeld, Hamerle, and Mayer 1989; Kiefer 1988.

21 See Greene 1993: Chapters 13-15 and 21; White 1980; White and Domowitz 1984; Newey and West 1987. Specific details on the specification implemented are available from the author. 
probability of adoption increases. For evidence of H2a, I would expect the coefficient of $P C S P E N D C H_{i t}$ to be positive; as expenditures rise, so does the probability a line-item veto will be adopted. For H2b, I would expect that the coefficients of either, or both, $L H S E A T_{i t}$ and $U H S E A T_{i t}$ to be positive. This would imply that legislatures with more seats would be more likely to adopt the line-item veto. For evidence of $\mathrm{H} 3 \mathrm{a}$, the coefficient of the interaction between $C O N_{i t}$ and $H I S T C O N_{i t}$ should be positive. This means that for confirmation of the conservative insulation hypothesis, I would expect if there is a conservative supermajority in the present legislature and historical conservative weakness in the legislature, the line-item veto is more likely to be adopted. Finally, for H3b, I would expect that both the interaction of CON $_{i t}$, HISTCON $_{i t}$, and HISTCONGOV $i t$ and LIB $i t, H_{i S T L I B}$, and HISTLIBGOV $i t$ to be positive. This test means that for evidence of the non-partisan insulation hypothesis, I would expect the probability of adoption of the item veto to rise if conservatives have a supermajority in both houses, if they have been historically weak, and if they have historically controlled the governorship; or the same for the liberals.

Results. Table 5 reports the results of a number of specifications of the econometric model described above, including basic specifications and a series of specifications to test for robustness. Model 1 includes only the dummy variable for supermajority conservative control $C O N_{i t}$. The next set of models considers the inclusion of all of the partisan measures. One problem which occurs when including all of the partisanship variables is multicollinearity. As an example, the auxiliary (OLS) regression of $C O N_{i t}$ on the remainder of the explanatory variables yields an $R$-squared of 0.97 . To eliminate this problem, I consider two specifications. First, Model 2 contains only the political variables which reflect the hypotheses of interest, excluding all main effects. Further, and perhaps more convincingly, Model 3 contains most of the main effects, making only restrictions on the most collinear variables. In particular, I eliminate the main effects on HISTLIB $B_{i t}$ and the interaction of HISTLIB ${ }_{i t}$ and HISTLIBGOV $V_{i t}$. Further, to reflect $\mathrm{H} 3 \mathrm{~b}$, I impose the constraint that the coefficients on the interaction of CON $i t$, HISTCON $i t$, and HISTCONGOV $i t$ and of LIB ${ }_{i t}, H_{\text {HSTLIB }}$ it, and HISTLIBGOV $V_{i t}$ to be equal. A specification test of this restricted model yields a likelihood ratio statistic of 3.58 with three degrees of freedom, with a p-value of 0.31 , indicating the restrictions are reasonable. 
Models 4 through 8 provide robustness tests for the results in Model 3. Models 4 and 5 consider controls for regional effects: Model 4 includes a dummy variable for Southern states, and Model 5 includes a full set of regional dummy variables. Model 6 includes a measure of duration, to test whether there is duration dependence. This measure is calculated for each state based on the introduction of the item veto, at the start of the sample. Models 7 and 8 consider alternative specifications of the econometric model, providing estimates for adoption of the item veto using a Cox proportional hazard model and Weibull hazard model. Models 9 and 10 add variables to examine $\mathrm{H} 2 \mathrm{a}$ and $\mathrm{H} 2 \mathrm{~b}$. Model 9 includes all of the variables for $\mathrm{H} 1$, $\mathrm{H} 3 \mathrm{a}$, and $\mathrm{H} 3 \mathrm{~b}$, as well as the measures of the size of the legislature, LHSEAT $i t$ and UHSEAT $T_{i t}$. Model 10 includes the expenditure variable for H2a, PCSPENDCH $H_{i t}$. Notably, this model is estimated only for the subset of the data for which the financial data are available. Model 11 provides another robustness check, as it rescores the variables for political weakness and strength based on prospective measures, which are the average of the three "forward" (rather than historical) lags of the relevant variables. Finally, in order to further understand $\mathrm{H} 3 \mathrm{~b}$, Model 12 relaxes the constraint on the interactions of $C O N_{i t}, H I S T C O N_{i t}$, and HISTCONGOV and of $L I B_{i t}, H I S T L I B_{i t}$, and HISTLIBGOV $V_{i t}$ allowing their coefficients to differ.

The results shown in Table 5 confirm H3a, the conservative insulation hypothesis. With only one exception, the legislative conservatism measure does not explain adoption. In all of these cases, the coefficient of the conservative party dummy is either insignificant or of the wrong sign. In other words, when controlling for other factors, the main effect of conservative control is not significant by itself. Thus, $\mathrm{H} 1$ is not supported by the data.

Similarly, the line-item veto is not a measure adopted by states that are facing an increasing fiscal commons problem. Model 9, a fully specified model which includes all of the partisan effects, yields an insignificant coefficient on the number of seats in the upper chamber and a significant, but negative coefficient on the number of seats in the lower chamber, leading to a rejection of $\mathrm{H} 2 \mathrm{~b}$. Similarly, Model 10, which includes the spending variable, yields a negative, if significant, coefficient on spending growth. This leads us to reject $\mathrm{H} 2 \mathrm{a}$. Indeed, the fact that the direction of the results are opposite to those the "efficiency" hypotheses would predict indicates that "profligate" legislatures, controlling for the effects of political interests encapsulated by $\mathrm{H} 3 \mathrm{a}$ and $\mathrm{H} 3 \mathrm{~b}$, understand their incentives and do not want to constrain themselves from acting on these incentives. 
The partisanship measures, however, paint a revealing picture about the dynamic insulation hypotheses H3a and H3b. First, consider the results in Model 3. Here, the interaction between conservative control and historical conservative weakness is positive and significant ( $p=0.039$ in a one-tailed test). Indeed, this result is remarkably robust. First, one concern about the specification in Model 3 is that remaining collinearity might cloud the results. However, in Model 2, when all main effects are excluded, the result is the same, albeit slightly weaker $(p=0.062){ }^{22}$ Similarly, in Model 4 , which controls for Southern states, and Model 5, which includes a full set of regional dummy variables, the coefficient is stable and significant $\left(p=0.043\right.$ and $p=0.032$, respectively) ${ }^{23}$ Similarly, even though the models correct for temporal dependence, another concern might be that the results are an artefact of the specific functional relationship assumed for time dependence. However, a number of alternative specifications for the hazard model yield similar results. For example, the result is unaffected by the inclusion of duration dependence, in Model $6 .{ }^{24}$ Further, I also estimate two forms of traditional hazard specifications, a Cox proportional hazards model (Model 7) and Weibull hazard model (Model 8). These two models also yield a similar result for H3a. Another concern - indeed as expressed by $\mathrm{H} 2 \mathrm{a}$ and $\mathrm{H} 2 \mathrm{~b}$ - might be that these partisan results are actually the result of correlation with some other feature of legislative behavior. However, although the results for the fiscal commons hypothesis were the opposite of those expected, inclusion of variables to measure the sharpness of the problem has no effect on the results of H3a. Finally, Model 11 considers whether the results are robust to the specific choice of measurement. Here, where I employ prospective measures of beliefs about future prospects, conservative control and prospective weakness in the legislature are jointly significant predictors of adoption of the item veto $(p \approx 0.000)$. In sum, although model specification causes a few of the main effects to change, the underlying relationship, that the line-item veto is more

\footnotetext{
22 An additional analysis, in which all regressors that have high correlations (greater than 0.80 ) are excluded yields similar results.

${ }^{23}$ Regressions in which Model 3 was estimated by region yield similar results, although in one case (for the west) the results do not hold. However, this is in part due to the limited number of adoptions included.

${ }^{24}$ Interestingly, the adoption process appears to include negative duration dependence, meaning that, controlling for other effects, the probability of adopting an item veto given that one has not been adopted, declines over time.
} 
likely to be adopted when there is conservative control and perceived future weakness, irrespective of the party of the governor, is stable. ${ }^{25}$

Although we obtain this result, it might also be true that liberals act the same way, which is the focus of $\mathrm{H} 3 \mathrm{~b}$, the non-partisan insulation hypothesis. In fact, the results here are less supportive. First, consider the effect of party control, that party's historical weakness and that party's historical control over the governorship. In the baseline political model (Model 3), this effect is positive and significant $(p=0.001)$, indicating support for $\mathrm{H} 3 \mathrm{~b}$. This result is tempered by a number of considerations, however. First, the result is not very stable. For example, inclusion of expenditure growth, or prospective measurement changes the sign of this coefficient to be negative. Second, if one excludes the effect of the governor, the coefficient of liberal control and historical liberal weakness is largely negative, a result which is inconsistent with the hypothesis. Most importantly, this result could be driven by confounding effects between the conservative interaction and the liberal interaction. In order to investigate this possibility, in Model 12, I relax the constraint imposed in Model 3 and find that the liberal and conservative effects act in the opposite direction. The positive coefficient on the constrained interaction terms seems to be entirely driven by the conservative effect.

In sum, the full set of results lead us to a number of conclusions. First, the item veto is not adopted in response to concerns about socially efficient policy outcomes. Second, while there is a conservative bias in the implementation of the item veto, this bias is not unconditional. Indeed, conservative legislatures are most likely to propose them when they feel they will be out of power in the future. In addition, this effect is strengthened even further when they are also confident that the governor will be of their own party. ${ }^{26}$

25 One other robustness analysis which was not reported here was an examination of the results by subperiods. Of particular concern is whether the coding of fiscal conservatives, which changes before and after 1913, appears invalid. In this case, I divided the sample into four periods: Reconstruction (1865-1877), postReconstruction but before the national income tax (1878-1912), after the national income tax until World War II (1913-1945), and post-War (1945+). Here, the results are also largely confirmatory. In three of the periods, and in particular in the first two, the results reported here hold. In the period between the institution of the national income tax and the end of World War II, the results do not hold for that period. There are a few of reasons for this which lessen the concern about the estimates in this period. First, there are very few adoptions in this period, second, there is much less variance in the independent variables.

26 Indeed, the significant, positive coefficient on the interaction of conservative control and a historically conservative governor seem to indicate that there is also a dynamic insulation effect simply from delegation by conservatives to a conservative governor. 
Finally, although analyzing the coefficients provides important evidence about why the item veto is adopted, the inclusion of (many significant) main effects, combined with the nonlinear model specification, makes it difficult to interpret the combined effects of the variables of interest. To help interpret the results, Table 6 shows how the predicted probabilities of adoption change when historical partisan legislative strength changes given a liberal and conservative supermajority respectively, at typical values of the included variables. $^{27}$ Two things stand out about these results. First, comparing the columns, there is a conservative bias for adoption (although each of the pairwise comparisons is not necessarily significant). More importantly, within the conservative column there is a strong effect of future electoral prospects. Indeed, a weak conservative legislature is more than twice as likely as a strong one to adopt the item veto. ${ }^{28}$

Table 6. Predicted Probability of Adopting Line-Item Veto

\begin{tabular}{ccc}
\hline \hline \multirow{2}{*}{$\begin{array}{c}\text { Historical Position } \\
\text { in Legislature }\end{array}$} & \multicolumn{2}{c}{ Current Supermajority Control } \\
Weak & Conservatives & Liberals \\
& 0.075 & 0.032 \\
& $(0.033)$ & $(0.033)$ \\
Average & 0.048 & 0.024 \\
& $(0.021)$ & $(0.016)$ \\
Strong & 0.033 & 0.029 \\
& $(0.018)$ & $(0.012)$ \\
\hline \hline
\end{tabular}

Note: Predicted probabilities based on Model 3

Standard errors in parentheses

Calculated based on each third of distribution of historical position and conditional mean values of other variables

27 In a traditional model, one might hold all of the variables at their means and consider marginal changes in one dimension. However, this is not sensible in this case for two of reasons: the distributions are somewhat skewed and the political variables are correlated. Therefore, the results show here partition the historical strength measures into each third of its range and choose average values within them. Further, I then use the conditional correlations between other measures such as control of the governorship to estimate the conditional values for each of these segments. This provides a better picture of the marginal effects for this model. 


\section{Discussion}

Elsewhere, I among others have argued that a critical aspect of policy implementation is the insulation of policies from future interference (de Figueiredo 2002; Moe 1989, 1990; Horn 1989). More importantly, the incentive to bear the costs of insulation are not identical for all actors. In particular, only those officials who feel that they have weak electoral prospects are willing to bear the potentially burdensome costs of insulating their programs. If an individual, group, or party, feels that it will be able to retain public authority for a long period, it would be much less willing to incur penalties to insulate programs from future interference, since in all likelihood, they will be the only ones with an opportunity to do so. Alternatively, if a group temporarily gains hold of public authority, it is much more likely to cede control now in order to obtain ongoing benefits in the future, when they are likely to be out of power.

In the context of the line-item veto, the analysis provides evidence that confirms this theory. The results indicate that the line-item veto can be interpreted as an insulation mechanism — when conservatives are usually in the minority they can protect their future interests by passing a line-item veto measure, given an opportunity to do so. Further, this insulation mechanism has costs: it means that the legislature must cede institutional power to the governor, and it means that the current majority must cede power to the current minority. The results, therefore, provide strong contributions to two literatures. In the first place, as noted, it provides evidence for a rethinking of the traditional theories on how political uncertainty affects policy implementation. Indeed, the results provide a more general watchword to those studying the effects of institutions. Here, the selection mechanism indicates that selection will be negatively correlated with the "normal" political conditions in a state. Second, it gives us a deeper understanding of the logic of state fiscal policy, and more generally, the legislative behavior of the states. The budgetary institutions of states are not necessarily adopted for economic efficiency_instead they are endogenous to the political institutions and environment.

\footnotetext{
28 A test that the predicted probability when strong is higher than when weak confirms this result $(p=0.098)$. The same does not hold for liberal control.
} 


\section{References}

Abrams, B. A., and W. R. Dougan. "The Effects of Constitutional Restraints on Government Spending." Public Choice 49 (1986), p. 112.

Alm, James and Mark Evers. "The Item Veto and State Government Expenditures." Public Choice 68 (1991), pp. 1-15.

Alt, James E. and Robert C. Lowry. "Divided Government, Fiscal Institutions, and Budget Deficits: Evidence from the States." American Political Science Review 88 (1994), p. 820.

Arnold, R. Douglas. The Logic of Congressional Action. Yale: New Haven, CT. 1990.

Baltagi, Badi Hani. Econometric Analysis of Panel Data. Chichester, UK, 1995.

Blossfeld, Hans-Peter, Alfred Hamerle, and Karl Ulrich Mayer. Event History Analysis: Statistical Theory and Application in the Social Sciences. Hillsdale, NJ. 1989.

Bradbury, John C. and Mark W. Crain. "Legislative Organization and Government Spending: Cross-Country Evidence." Journal of Public Economics 82 (2001), pp. 309-325.

Burnham, Walter Dean. Inter-University Consortium for Political and Social Research. Partisan Divisions Among the States, 1830-1985.

Carter, John R. and David Schap. “Line Item Veto: Where is Thy Sting?” Journal of Economic Perspectives 4 (1990), pp. 103-118.

Council of State Governments. The Book of the States, Volumes 1-30. Council of State Governments: Lexington, KY, 1935-1994.

Cox, Gary W. and Mathew D. McCubbins. Legislative Leviathan. University of California: Los Angeles. 1993.

Crain, Mark W. and James Miller. "Budget Process and Spending Growth." William and Mary Law Review (Spring 1990), pp. 1021-1046.

de Figueiredo, Rui J. P. Jr.. "Electoral Competition, Political Uncertainty and Policy Insulation." American Political Science Review (2002).

Dearden, James A., and Thomas A. Husted. "'Do Governors Get What They Want?: An Alternative Examination of the Line-Item Veto." Public Choice 77 (1993), p 710.

Fisher, Louis and Neal Devins. "How Successfully Can the States' Item Veto be Transferred to the President." Georgetown Law Journal 75 (1986), p. 159-197. 
Gilligan, Thomas W. and John G. Matsusaka. "Deviations from Constituent Interests: The Role of Legislative Structure and Political Parties in the States." Economic Inquiry 33 (1995), pp. 383-401.

Gilligan, Thomas W. and John G. Matsusaka. "Fiscal Policy, Legislature Size, and Political Parties: Evidence from State and Local Governments in the First Half of the $20^{\text {th }}$ Century." National Tax Journal 54 (2001), pp. 57-82.

Greene, William H. Econometric Analysis. New York. 1993.

Holtz-Eakin, Douglas. "The Line-item Veto and Public Sector Budgets." Journal of Public Economics 36 (1988), pp. 272-273.

Horn, Murray. "The Political Economy of Public Administration: Organization, Control and Performance of the Public Sector." Harvard University Thesis. 1989.

Johnson, Donald Bruce, and Kirk H. Porter, eds. National Party Platforms, 1840-1972. Champagne, IL. 1973.

Kiefer, Ronald. "Economic Duration Data and Hazard Functions." Journal of Economic Literature 26 (1988), pp. 646-678.

Moe, Terry M. "The Politics of Bureaucratic Structure." In John E. Chubb and Paul E. Peterson, eds. Can the Government Govern? Washington, DC: Brookings, 1989.

Moe, Terry M. "The Politics of Structural Choice: Towards a Theory of Public Bureaucracy." In Oliver E. Williamson, ed. Organization Theory: From Chester Barnard to the Present and Beyond . University of California: Berkeley, CA, 1990.

Newey, Whitney K. and Kenneth D. West. "A Simple, Positive Semi-Definite, Heteroskedasticity and Autocorrelation Consistent Covariance Matrix." Econometrica 55 (1987), pp. 703-708.

North, Douglass and Barry R. Weingast. "Constitutions and Commitment: Evolution of Institutions Governing Public Choice." Journal of Economic History 49 (1989), pp. 803832.

Petterson-Lidbom, Per. "Does the Size of the Legislature Affect the Size of the Government? A Natural Experiment.” Working Paper. 2001.

Palffy, John. "Line-Item Veto: Trimming the Pork." The Backgrounder (1994), pp. 1-12.

Poterba, James M. "State Responses to Fiscal Crises: The Effects of Budgetary Institutions and Politics," Journal of Political Economy 102 (1994), pp. 799-821. 
Poterba, James M. "Budget Institutions and Fiscal Policy in the U.S. States," The American Economic Review 86 (1996), pp. 395-400.

Rowley, C. K. , W. F. Shughart, and R. D. Tollison. "Interest Groups and Deficits." In J. M. Buchanan, C. K. Rowley, and R. D. Tollison, eds. Deficits. New York, 1987.

Sylla, Richard, John Wallis, and John Legler. ICPSR. Sources and Uses of Funds in State and Local Governments, 1790-1915: United States.

United States Department of Commerce, Bureau of the Census. Compendium of State Government Finances. Annual serial. G-SF Series No. 2. 1942-1964. Washington.

United States Department of Commerce, Bureau of the Census. Financial Statistics of States. Annual serial. 1915-1931, 1937-1941. Washington.

United States Department of Commerce, Bureau of the Census. Historical Statistics of the United States: Colonial Times to 1970, Vols. 1 and 2. Washington. 1975.

United States Department of Commerce, Bureau of the Census. State Government Finances. Annual serial. GF Series, No. 3. 1965-1981. Washington.

United States Department of Commerce, Bureau of the Census. Statistical Abstract of the United States. Annual serial. 1980-1996. Washington.

United States House of Representatives, Committee on Rules. Item Veto: State Experience and Its Application to the Federal Situation. 1986. Washington.

Vanden Bergh, Richard G. and Rui J. P. de Figueiredo, Jr. "Political Uncertainty and Administrative Procedures." In Barry Burden, ed., Uncertainty in American Politics. Princeton University Press, forthcoming.

Weingast, Barry R. and William J. Marshall. "The Industrial Organization of Congress; or Why Legislatures, Like Firms, Are Not Organized as Markets." Journal of Political Economy 96 (1988), pp. 132-163.

Weingast, Barry R., Kenneth A. Shepsle, and Christopher Johnsen. "The Political Economy of Benefits and Costs: A Neoclassical Approach to Distributive Politics." Journal of Political Economy 93 (1981), pp. 642-664.

White, Halbert. "A Heteroscedasticity-Consistent Covariance Matrix Estimator and a Direct Test for Heteroscedasticity." Econometrica 48 (1980), pp. 817-838.

White, Halbert and Ian Domowitz. "Nonlinear Regression with Dependent Observations." Econometrica 52 (1984), pp. 143-161.

Yamaguchi, Kazuo. Event History Analysis. Newbury Park, CA. 1991. 